\title{
Pemanfaatan Database EBSCO dan ProQuest sebagai Rujukan Penyusunan Tesis dan Disertasi bagi Mahasiswa Program Magister Sains dan Doktor Fakultas Ekonomika dan Bisnis UGM: Analisis Sitiran Jurnal Ilmiah***)
}

\author{
Maryatun(*) \\ e-mail:maryatun@ugm.ac.id \\ Pergola Irianti $(* *)$ \\ e-mail:pergola@ugm.ac.id
}

\begin{abstract}
This study aims to examine the utilization of e-journals in EBSCO database "Business Source Complete" and ProQuest "ABI / INFORM Collection" as the citation in the writing of theses and dissertations by the students of Master of Science and Doctor of the Faculty of Economics and Business Universitas Gadjah Mada 2014-2015. This quantitative descriptive study used documentation method for data collection. Data analysis used frequency tabulation and percentage calculation of Kerlinger's formulas.

The results showed that the availability of journals in the EBSCO database for the preparation of theses and dissertations was higher than in ProQuest. The degree of duplication of availability of journals both in EBSCO and ProQuest for the preparation of theses and dissertations of all majors was $24.88 \%$ and $27.81 \%$ respectively. Journals published between 2001-2010 was more highly utilized. Overall the utilization of these two databases was low.
\end{abstract}

Keywords: citation analysis, EBSCO, ProQuest, e-journals

*) Pustakawan UGM bertugas di Perpustakaan Fakutas Ekonomika dan Bisnis

**) Pustakawan UGM bertugas di Perpustakaan Fakultas Psikologi

***) Pemenang Hibah Penelitian Perpustakaan UGMtahun 2016

\section{A. PENDAHULUAN}

Rencana strategis Universitas Gadjah Mada (UGM) tahun 2012-2017 yakni menjadi perguruan tinggi terbaik di Indonesia dan menyandang reputasi internasional melalui produk penelitian yang menjadi rujukan nasional berwawasan lingkungan dan responsif terhadap permasalahan masyarakat, bangsa dan negara yang berbasis pada nilai-nilai keunggulan local. Hasil penelitian dosen dan mahasiswa UGM berpotensi menjadi produk unggulan dan sumber pendapatan universitas, dan dapat dipublikasikan untuk pengembangan ilmu pengetahuan dan meningkatkan kesejahteraan masyarakat.

Berdasarkan data dari SCImago Journal \& Country Rank di tingkat ASEAN, jumlah publikasi Indonesia lebih rendah dari Malaysia. Oleh karena itu Dirjen Pendidikan Tinggi mengeluarkan surat edaran Nomor 152/E/T/2012 tentang publikasi karya ilmiah. Isi surat edaran tersebut mewajibkan mahasiswa dapat menghasilkan karya ilmiah yang dimuat pada jurnal ilmiah untuk mahasiswa program sarjana. Selanjutnya untuk mahasiswa program magister dan doktor, masing-masing menyajikan karyanya pada jurnal nasional terakredikasi LIPI (Lembaga Ilmu Pengetahuan Ilmiah), dan jurnal internasional bereputasi.

Kebijakan tersebut mengarah pada peningkatan kuantitas dan kualitas karya ilmiah Indonesia, dengan harapan dapat diterima dalam penerbitan jurnal nasional terakreditasi dan jurnal internasional terkemuka (leading journal). Untuk mewujudkan hal tersebut diperlukan infrastruktur pendukung penelitian dan publikasi, antara lain tersedianya database e-journal sesuai kebutuhan sivitas akademika. 
Sejak tahun 2005 Perpustakaan UGM telah melanggan database elektronik, dan EBSCO merupakan database yang pertama kali dilanggan. Pada tahun-tahun berikutnya, UGM memperluas langganan database selain EBSCO, antara lain: ProQuest, JStor, IEEE, Clinical Key, dan lainnya. Database EBSCO dan ProQuest merupakan industri bisnis informasi yang dikenal sebagai database aggregators, yaitu basis data yang menyediakan berbagai jenis sumber daya elektronik, dan salah satunya berupa e-journal. Kedua industri bisnis informasi tersebut secara khusus menyediakan jenis sumber informasi bidang ekonomi, yaitu database Business Source Complete pada database EBSCO dan ABI/INFORM Complete pada database ProQuest. Masing-masing database berisi ejournal yang sudah ditentukan judul jurnalnya oleh pihak vendor, dengan demikian sumber informasi yang tersedia berupa paket atau sistem paket. Sistem paket memiliki kelebihan dan kelemahan, yaitu terjadinya duplikasi atau kesamaan judul e-journal pada dua database yang dilanggan, sedangkan kelebihannya yaitu harga langganan lebih murah dibandingkan dengan melanggan secara terpisah masingmasing judul jurnal.

Penyediaan, pemanfaatan, dan evaluasi terhadap sumber informasi elektronik yang dibutuhkan sivitas akademika menjadi tanggung jawab perpustakaan secara penuh. Kemampuan evaluasi pustakawan terhadap penggunaan sumber informasi elektronik diharapkan dapat berdampak secara signifikan untuk menentukan keberlangsungan atau penghentian database yang dilanggan (Surachman, 2014).

Berdasarkan uraian tersebut, permasalahan yang perlu dijawab dalam penelitian ini: Bagaimana pemanfaatan e-journal dalam database EBSCO "Business Source Complete" dan database ProQuest "ABI/INFORM Complete" sebagai rujukan penyusunan tesis dan disertasi bagi mahasiswa program magister sains dan doktor Fakultas Ekonomika dan Bisnis (FEB) UGM?

Tujuan penelitian untuk mengetahui pemanfaatan e-journal dalam database EBSCO "Business Source Complete" dan ProQuest "ABI/INFORM Complete" sebagai rujukan penyusunan tesis dan disertasi mahasiswa program magister sains dan doktor FEB UGM, antara lain: (1) mengetahui judul-judul ejournal dalam dua database tersebut yang dimanfaatkan dalam penyusunan tesis dan disertasi. (2) Mengetahui jumlah dan persentase ketersediaan e-journal dalam dua database tersebut yang disitir dalam penyusunan tesis dan disertasi. (3) Mengetahui tingkat kesamaan judul e-journal dalam dua database tersebut sebagai rujukan penyusunan tesis dan disertasi. (4) Mengetahui tahun terbit jurnal sebagai rujukan penyusunan tesis dan disertasi. (5) Mengetahui frekuensi pemanfaatannya dalam penyusunan tesis dan disertasi.

Manfaat yang diharapkan dari penelitian antara lain: (1) Memberikan informasi tingkat pemanfaatan e-journal dalam dua database tersebut sebagai rujukan penyusunan tesis dan disertasi. (2) Sebagai bahan masukan dan evaluasi penentuan kebijakan pengembangan sumber informasi elektronik, khususnya langganan e-journal di Perpustakaan FEB khususnya dan UGM pada umumnya. (3) Menambah wawasan bagi pembaca tentang pemanfaatan dan pengelolaan e-journal.

\section{B. TINJAUAN PUSTAKA}

\section{Keaslian Penelitian}

Penelitian analisis sitiran telah dilakukan di dalam maupun di luar negeri. Beberapa penelitian mengenai analisis sitiran pada tesis dan disertasi di luar negeri antara lain dilakukan oleh Abeyrathne (2015), Becker (2015), Banateppanvar(2013), Thanuskodi(2012), Iinoven (2009), Feyereisen (2009), hasilnya menunjukkan bahwa jenis koleksi jurnal lebih tinggi disitir daripada jenis koleksi yang lain. Sementara Gasparotto (2014) melakukan penelitian tentang analisis bibliografi pada disertasi, ditemukan bahwa koleksi buku paling banyak disitir daripada jurnal.

Anyaoku (2014) melakukan kajian pemanfaatan database HINARI, pada Nigerian Journal of Clinical Preactice, menemukan bahwa $42,8 \%$ judul jurnal tersedia, dan $57,2 \%$ tidak tersedia di database tersebut. Penelitian di Indonesia oleh Purwaningsih (2013) tentang pemanfaatan jurnal dalam database EBSCO dalam penyusunan skripsi Jurusan Akuntansi FEB UGM tahun 2011. 
Hasilnya menunjukkan bahwa pemanfaatan jurnal yang bersumber dari database EBSCO hanya sebesar $13,79 \%$, sementara ketersediaannya mencapai $59,88 \%$.

Hal tersebut menunjukkan bahwa analisis sitiran untuk mengkaji pemanfaatan jenis informasi dalam penyusunan tesis dan disertasi telah banyak dilakukan di berbagai universitas, dan jurnal merupakan jenis sumber informasi yang menempati ranking tertinggi. Meskipun demikian penelitian yang berkaitan dengan database penyedia informasi jurnal untuk penyusunan tesis dan disertasi masih sedikit dilakukan. Oleh karena itu penulis tertarik untuk melakukan penelitian pemanfaatan jurnal dalam database untuk penyusunan tesis dan disertasi di FEB UGM, karena sepengetahuan penulis penelitian ini belum pernah dilakukan.

\section{Jurnal Elektronik dan Pemanfaatannya}

Definisi jurnal elektornik menurut International Encyclopedia of Information and Library Sciences (Feather and Strges, 1997) adalah : "a term used to describe a journal that is published in digital form to be displayed on a computer screen". Jurnal elektronik dideskripsikan sebagai sebuah jurnal yang diterbitkan dalam format digital dan ditampilkan di layar komputer. Menurut Lasa Hs (2009) jurnal elektronik adalah jurnal yang disajikan secara elektronik sejak penyiapan, review, penerbitan, dan penyebarannya. Mahalnya biaya pencetakan jurnal dan kemajuan teknologi komputer, serta meluasnya world wide web akhir-akhir ini memicu kehadiran jurnal dalam bentuk elektronik. Berdasarkan uraian tersebut disimpulkan bahwa jurnal elektronik adalah jurnal yang diterbitkan dalam format digital dan dapat diakses menggunakan media elektronik, seperti melalui web atau akses internet.

Jurnal elektronik sebagai publikasi ilmiah dalam format elektronik mempunyai International Standard Serial Number (ISSN) dengan format dokumen dalam bentuk PDF (Rusydi, 2014). Keuntungan jurnal elektronik antara lain: (a) relatif murah, (b) menghemat tempat, (c) dapat dimanfaatkan oleh banyak orang secara bersamaan, (d) lebih cepat disajikan, (e) tidak memerlukan proses pengolahan seperti jurnal cetak, dan (f) penerbitannya lebih cepat (Lasa Hs., 2009). Dikemukakan oleh Woodward et.al (1998) bahwa jurnal elektronik memberi kemudahan menemukan informasi yang spesifik dengan cepat dan tersedia beberapa format seperti teks, grafik, atau full image.

Kata "pemanfaatan" berasal dari kata dasar manfaat, yang berarti guna; faedah, sedangkan pemanfaatan berarti proses, cara, perbuatan memanfaatkan (Kamus Besar Bahasa Indonesia, 2005). Pemanfaatan jurnal merupakan penggunaan jurnal untuk kepentingan penulisan artikel ilmiah yang dibuktikan dengan dicantumkannya jurnal tersebut dalam kutipan maupun pada daftar pustaka, atau dengan kata lain disitir dan tercantum pada daftar pustaka (Irianti, 2007). Secara umum pemanfaatan jurnal elektronik merupakan aktivitas pengguna dalam menggunakan jurnal untuk memenuhi kebutuhan informasi (Wiratningsih, 2011).

Jadi pemanfaatan jurnal dalam penelitian ini yakni evaluasi tentang penggunaan jurnal dalam database EBSCO dan ProQuest sebagai rujukan penyusunan tesis dan disertasi yang dapat dibuktikan dengan dicantumkan artikel jurnal dalam daftar pustaka karya yang bersangkutan.

\section{Analisis Sitiran}

Analisis sitiran merupakan cabang bibliometrika yang meneliti kutipan dalam publikasi seperti jurnal, artikel, dan buku untuk mencari pola penggunaan suatu dokumen (Hoffmann and Doucette, 2012). Analisis sitiran pertama kali ditandai dengan munculnya karya Garfield tahun 1955 berjudul "Citation Indexes from Sciences" sebagai tonggak analisis sitiran pada waktu itu sampai saat ini (SulistyoBasuki, 2002). Analisis sitiran merupakan penghitungan sejumlah sitiran berdasarkan frekuensi sebuah dokumen disitir (Cooper, 2015). Hasil analisis sitiran dengan obyek penelitian disertasi dapat digunakan pustakawan perguruan tinggi membantu 
membuat keputusan efektif dalam pengembangan koleksi dan sebagai indikator pemanfaatan koleksi oleh mahasiswa (Haycock, 2004).

Menurut Hartinah (2002) analisis sitiran berguna untuk menentukan berbagai kepentingan atau kebijakan antara lain: (a) evaluasi program riset, (b) pemetaan ilmu pengetahuan, (c) visualisasi suatu disiplin ilmu, (d) indikator IPTEK, (e) pengembangan koleksi majalah/jurnal, dan lain-lain. Lebih rinci Sulistyo-Basuki (1994) membagi penggunaan teknik analisis sitasi dalam kategori sebagai berikut: (a) Pengembangan koleksi dan kajian pemakai. Analisis sitiran digunakan untuk merumuskan kebijakan pengembangan berbagai jenis koleksi berdasarkan frekuensi disitir. Penggunaan lainnya untuk menentukan keberlanjutan atau penghentian langganan jurnal berdasarkan frekuensi jurnal disitir. (b) Temu balik informasi, analisis sitiran digunakan untuk mengembangkan pengganti dokumen, hubungan kata kunci dokumen - pemakai dan strategi penelusuran, identifikasi berbantuan komputer mengenai artikel yang menyitir dan akses terhadap literatur interdisipliner. (c) Pengembangan dan pertumbuhan subyek dan literatur subyek, produktivitas pengarang dan pengaruhnya terhadap pengarang lain diukur melalui sitiran. (d) Kajian historis dan penelitian yang sedang berlangsung, mencakup kegiatan melacak pengembangan sebuah subyek melalui kaidah waktu. (e) Pola komunikasi penelitian., berupa kajian dampak isolasi karena kendala bahasa, jarak, ketersediaan literatur ilmiah, dan masalah komunikasi. (f) Menghitung paro hidup sebuah bidang ilmu, yaitu usia dari separo literatur yang digunakan dalam sebuah bidang. Paro hidup menunjukkan kecepatan pertumbuhan literatur termasuk pertumbuhan ilmu, sehingga semakin muda paro hidup sebuah bidang ilmu, semakin cepat perkembangan ilmu tersebut. (g) Penyusunan indeks sitiran.

\section{Database EBSCO dan ProQuest}

Database EBSCO merupakan database aggregator yang memuat publikasi dari berbagai penerbit dan jenis terbitan lainnya. Sebagai database aggregator beberapa judul dalam database EBSCO mengalami embargo yang membatasi akses terhadap full text hingga waktu tertentu. Tampilan menu database Business Source Complete dapat dilihat pada gambar di bawah ini.

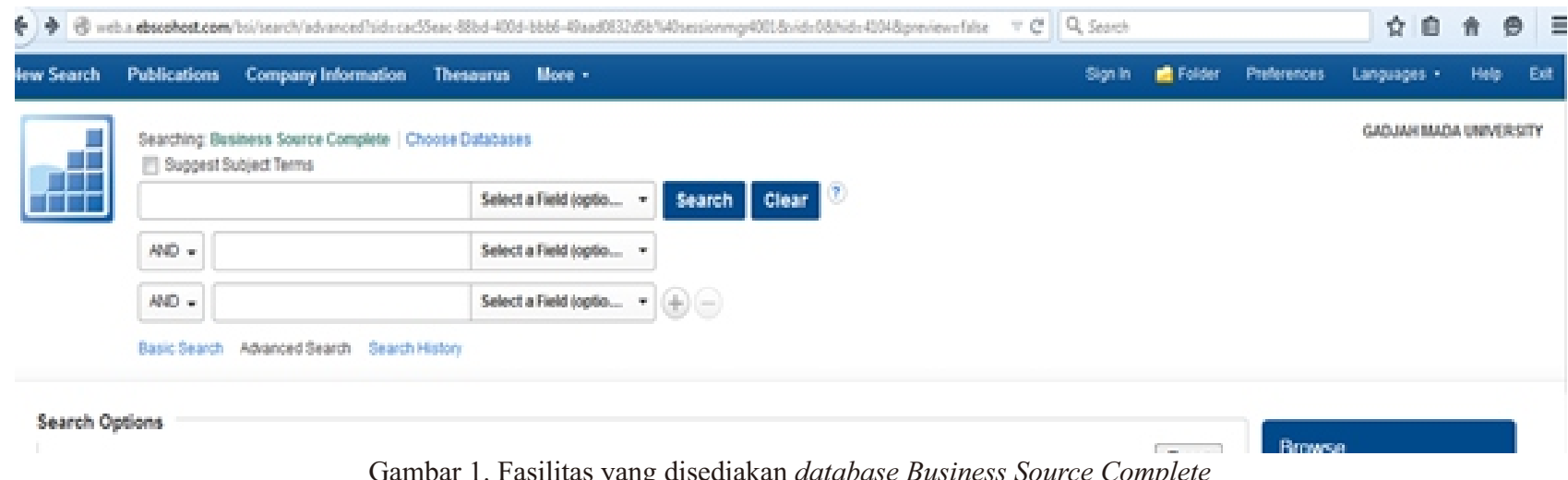

Gambar 1. Fasilitas yang disediakan database Business Source Complete

Database ProQuest merupakan contoh database aggregator, yaitu basis data yang menyediakan berbagai jenis sumber daya elektronik seperti e-journal, e-book, eproceeding, e-paper dan lain-lain yang diperoleh dari satu atau lebih penerbit atau penyedia konten elektronik (Surachman, 2014). Salah satu database bidang ekonomi yang terdapat di database tersebut yaitu ABI/INFORM Complete yang dilanggan UGM. Database ABI/INFORM Complete memuat subyek bisnis, manajemen dan perdagangan, laporan data pasar, industri, kasus bisnis dan berita-berita perdagangan tingkat global. Tampilan menu database ABI/INFORM dapat dilihat pada gambar 2. 


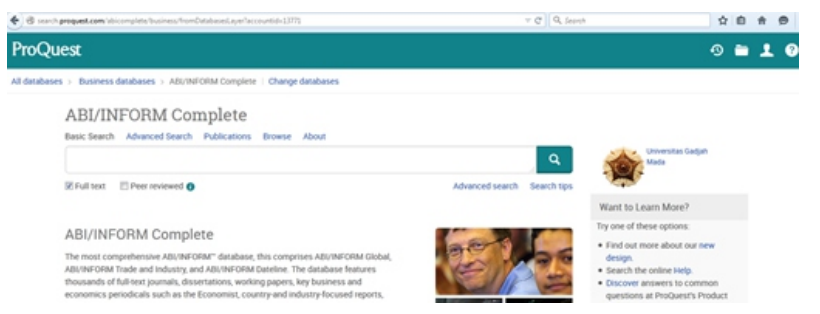

Gambar 2. Fasilitas yang disediakan database ABI/INFORM

\section{METODE PENELITIAN}

Penelitian ini menggunakan metode deskriptif kuantitatif. Metode deskriptif dimaksudkan untuk mendiskripsikan secara sistematis, faktual, dan akurat mengenai faktafakta dan sifat-sifat populasi (Suryabrata, 1983 ). Secara kuantitatif dapat menggambarkan atau menjelaskan suatu permasalahan yang ada (Kriyantono, 2007).

Subjek penelitian adalah sumber data dalam penelitian, sedangkan objek penelitian adalah apa yang menjadi titik perhatian suatu penelitian (Arikunto, 2002). Tesis dan disertasi mahasiswa program magister sains dan doktor FEB UGM tahun 2014-2015, menjadi subjek dalam penelitian ini dan sekaligus menjadi populasi penelitian, dengan objek berupa jurnal dalam database EBSCO "Business Source Complete" dan ProQuest "ABI/INFORM Complete" yang disitir dan tercantum dalam daftar pustaka tesis dan disertasi mahasiswa program magister sains dan doktor FEB UGM tahun 2014-2015

Metode pengumpulan data menggunakan metode dokumentasi, yaitu pengumpulan data menggunakan bahan-bahan tertulis sebagai dokumen (Nawawi, 2006). Dokumen dalam penelitian ini berupa daftar pustaka dari subjek penelitian dan literatur pendukung yang dijadikan bahan rujukan.

Metode analisis menggunakan tabel frekuensi dalam persentase. Penghitungan persentase menggunakan rumus dari Kerlinger (1973), sebagai berikut:

$$
\text { Persentase }=\text { Proporsi } \times 100
$$

Proporsi merupakan pecahan yang pembilangnya yaitu satu di antara dua frekuensi atau lebih, sedangkan penyebutnya yaitu jumlah seluruh frekuensi terobservasi.

Hasil analisis yang diperoleh selanjutnya diinterpretasi menggunakan analisis data dari Arikunto (1998) sebagai berikut:

- Nilai $81-100 \%$ : sangat baik

- Nilai $61-80 \%$ : baik

- Nilai $41-60 \%$ : cukup

- Nilai $21-40 \%$ : kurang

- Nilai 0-20\% : sangat kurang

D. HASIL PENELITIAN DAN PEMBAHASAN

1. Sitiran pada Tesis dan disertasi 2014 2015 Program Magister Sains dan Doktor FEB UGM

Jumlah tesis dan disertasi periode 2014-2015 masing-masing berjumlah 188 judul dan 40 judul untuk semua jurusan yang ada. Jumlah sitiran jurnal secara keseluruhan pada tesis dan disertasi masing-masing 7538 dan 3518 sitiran. Rincian selengkapnya disajikan pada tabel 1 .

Tabel 1.

Sebaran jumlah dan rerata sitiran pada tesis dan disertasi masing-masing jurusan di FEB Universitas Gadjah Mada 2014-2015

\begin{tabular}{llccc}
\hline \multirow{2}{*}{ Jenis Karya Tulis } & \multicolumn{1}{c}{ Jurusan } & Jumlah & Jumlah sitiran Jurnal & Rerata sitiran \\
\hline \multirow{3}{*}{ Tesis } & Akuntansi & 71 & 2890 & 41 \\
\cline { 2 - 5 } & Manajemen & 62 & 3535 & 57 \\
\cline { 2 - 5 } Jumlah & Ilmu Ekonomi & 55 & 1113 & 20 \\
\hline \multirow{3}{*}{ Disertasi } & Akuntansi & 188 & 7538 & 70 \\
\cline { 2 - 5 } & Manajemen & 19 & 1465 & 120 \\
\hline Jumlah & Ilmu Ekonomi & 11 & 846 & 77 \\
\hline
\end{tabular}

Sumber: Data diolah 2016 
Pada tabel di bawah ini terlihat rerata penggunaan jurnal untuk penyusunan karya tulis mahasiswa program magister sains dan doktor FEB Jurusan Manajemen lebih banyak menggunakan sitiran jurnal dibandingkan karya tulis mahasiswa Jurusan Akuntansi maupun Jurusan Ilmu Ekonomi. Rerata sitiran jurnal dalam tesis sebanyak 40 jurnal, sedangkan dalam disertasi sebanyak 92 jurnal. Hal ini mengindikasikan bahwa jurnal lebih relevan dan mutakhir untuk pembahasan subyek yang lebih mendalam.

\section{Judul-judul Jurnal Disitir}

Dalam penyusunan tesis dan disertasi program magister sains dan doktor FEB UGM periode 2014-2015 pada masing- masing jurusan (Akuntansi, Manajemen, Ilmu Ekonomi) ditemukan 20 besar judul jurnal disitir. Tabel berikut ini menyajikan sebaran jurnal disitir pada masing-masing jurusan baik dalam tesis maupun disertasi.

Tabel 2 menunjukkan bahwa frekuensi sitiran terhadap jurnal Academy of Management Journal menduduki peringkat tertinggi yaitu sebanyak 153 kali, diikuti Accounting Review sebanyak 133 kali, masing-masing pada tesis Jurusan Manajemen dan Jurusan Akuntansi. Pada Jurusan Ilmu Ekonomi, sitiran jurnal tertinggi pada American Economic Review. Hal ini mengindisikasikan bahwa masingmasing judul jurnal tersebut merupakan jurnal inti yang sangat dibutuhkan oleh mahasiswa pada masing-masing jurusan tersebut.

Tabel 2. Sebaran 20 besar jurnal disitir dalam tesis pada tiga jurusan di FEB UGM

\begin{tabular}{|c|c|c|c|c|c|c|}
\hline \multirow[t]{2}{*}{ No } & \multirow{2}{*}{$\begin{array}{c}\text { Jurusan Akuntansi } \\
\text { Judul } \\
\end{array}$} & \multicolumn{3}{|c|}{ Jurusan Manajemen } & \multicolumn{2}{|l|}{ Jurusan Ilmu Ekonomi } \\
\hline & & Frek & Judul & Frek & Judul & Frek \\
\hline 1 & Accounting Review & 133 & $\begin{array}{l}\text { Academy of } \\
\text { Management Journal }\end{array}$ & 153 & American Economic Review & 35 \\
\hline 2 & Journal of Business Ethics & 89 & Journal of Applied Psychology & 112 & Journal of Political Economy & 29 \\
\hline 3 & MIS Quarterly & 76 & Journal of Finance & 104 & Journal of Urban Economics & 26 \\
\hline 4 & $\begin{array}{l}\text { Accounting, Organizations } \\
\text { and Society }\end{array}$ & 59 & $\begin{array}{l}\text { Academy } \\
\text { of Management Review }\end{array}$ & 98 & World Development & 26 \\
\hline 5 & $\begin{array}{l}\text { Journal of Accounting } \\
\text { and Economics }\end{array}$ & 58 & Journal of Marketing & 98 & $\begin{array}{l}\text { Journal of International } \\
\text { Economics }\end{array}$ & 25 \\
\hline 6 & Journal of Applied Psychology & 53 & Journal of Financial Economics & 85 & Quarterly Journal of Economics & 25 \\
\hline 7 & Journal of Accounting Research & 48 & Strategic Management Journal & 62 & $\begin{array}{l}\text { Journal of Development } \\
\text { Economics }\end{array}$ & 22 \\
\hline 8 & $\begin{array}{l}\text { Academy of Management } \\
\text { Review }\end{array}$ & 43 & $\begin{array}{l}\text { Journal of Organizational } \\
\text { Behavior }\end{array}$ & 59 & $\begin{array}{l}\text { Journal of International } \\
\text { Money and Finance }\end{array}$ & 18 \\
\hline 9 & Managerial Auditing Journal & 38 & Journal of Consumer Research & 56 & Econometrica & 18 \\
\hline 10 & Journal of Marketing & 35 & Organization Science & 48 & $\begin{array}{l}\text { Bulletin of Indonesian } \\
\text { Economic Studies }\end{array}$ & 15 \\
\hline 11 & Academy of Management & 35 & Journal of Knowledge & 41 & Economic Journal & 15 \\
\hline & Journal & & Management & & & \\
\hline 12 & Information Systems Research & 34 & Journal of Marketing Research & 41 & Journal of Banking and Finance & 15 \\
\hline 13 & Journal of Financial Economics & 32 & Journal of Banking and Finance & 40 & Journal of Monetary Economics & 14 \\
\hline 14 & Information and Management & 31 & $\begin{array}{l}\text { Administrative Science } \\
\text { Quarterly }\end{array}$ & 37 & Journal of Economic Growth & 12 \\
\hline 15 & $\begin{array}{l}\text { Journal of Management } \\
\text { Information Systems }\end{array}$ & 29 & $\begin{array}{l}\text { Journal of the Academy of } \\
\text { Marketing Science }\end{array}$ & 34 & $\begin{array}{l}\text { Journal of Economic } \\
\text { Perspectives }\end{array}$ & 12 \\
\hline 16 & $\begin{array}{l}\text { Contemporary Accounting } \\
\text { Research }\end{array}$ & 25 & Journal of Business Research & 32 & Journal of Financial Stability & 10 \\
\hline 17 & $\begin{array}{l}\text { Journal of Personality and social } \\
\text { Psychology }\end{array}$ & 25 & $\begin{array}{l}\text { Journal of personality and } \\
\text { social psychology }\end{array}$ & 32 & $\begin{array}{l}\text { Review of Economics } \\
\text { and Statistics }\end{array}$ & 10 \\
\hline 18 & Public Administration Review & 25 & Journal of Vocational Behavior & 31 & World Bank Economic Review & 10 \\
\hline 19 & $\begin{array}{l}\text { Behavioral Research in } \\
\text { Accounting }\end{array}$ & 24 & Journal of Advertising & 29 & Journal of Economic Literatur & 9 \\
\hline 20 & Journal of Business Research & 24 & Journal of Business Ethics & 28 & Journal of Public Economics & 9 \\
\hline dst & $\begin{array}{l}\text { World Institute for Development } \\
\text { Economics Research } \\
\text { dan judul jurnal lainnya... }\end{array}$ & & $\begin{array}{l}\text { Chapter } 2 \text { Journal marketing } \\
\text { Inteligence and Planning } \\
\text { dan } 508 \text { judul jurnal lainnya }\end{array}$ & Chapter 31 & $\begin{array}{l}\text { World Bank Research Observer } \\
\text { dan } 268 \text { judul jurnal lainnya }\end{array}$ & 1 \\
\hline
\end{tabular}

Sumber: Data diolah 2016 
Setelah dilakukan pengecekan pada database EBSCO dan ProQuest dari 20 besar jurnal yang digunakan, ditemukan beberapa judul jurnal yang tidak terdapat pada dua database tersebut. Rincian selengkapnya dapat dilihat pada tabel 3 .
Pada tabel 4 terlihat bahwa Accounting of Review merupakan jurnal dengan frekuensi tertinggi disitir 156 kali pada disertasi jurusan Manajemen Program Doktor. Sementara pada Jurusan Manajemen dan Ilmu Ekonomi masing-

Tabel 3. Daftar jurnal tidak tersedia pada database EBSCO dan ProQuest untuk penyusunan tesis pada tiga jurusan di FEB UGM

\begin{tabular}{clll}
\hline \multirow{2}{*}{ No } & \multicolumn{1}{c}{ Jurusan Akuntansi } & \multicolumn{1}{c}{ Jurusan Manajemen } & \multicolumn{1}{c}{ Jurusan Ilmu Ekonomi } \\
\cline { 2 - 4 } & \multicolumn{1}{c}{ Judul } & Judul & \multicolumn{1}{c}{ Judul } \\
\hline 1 & Accounting & Journal of Financial Economics & Journal of Urban Economics \\
\hline 2 & Organizations and Society & Journal of Banking and Finance & World Development \\
\hline 3 & Journal of Accounting and Economics & Journal of Business Research & Journal of International Economics \\
\hline 4 & Journal of Financial Economics & Journal of Vocational Behavior & Journal of International Money and Finance \\
\hline 5 & Information and Management & & Journal of Banking and Finance \\
\hline 6 & Journal of Business Research & & Journal of Monetary Economics \\
\hline 7 & & & Journal of Financial Stability \\
\hline 8 & & Journal of Public Economics. \\
\hline
\end{tabular}

Sumber: Data diolah 2016

Tabel 4. Sebaran 20 besar jurnal disitir dalam disertasi pada tiga jurusan di FEB UGM

\begin{tabular}{|c|c|c|c|c|c|c|}
\hline \multirow{2}{*}{ No } & \multicolumn{2}{|l|}{ Jurusan Akuntansi } & \multicolumn{2}{|l|}{ Jurusan Manajemen } & \multicolumn{2}{|l|}{ Jurusan Ilmu Ekonomi } \\
\hline & Judul & Frek & Judul & Frek & Judul & Frek \\
\hline 1 & Accounting Review & 156 & Journal of Business Ethics & 56 & American Economic Review & 30 \\
\hline 2 & $\begin{array}{l}\text { Journal of Accounting } \\
\text { and Economics. }\end{array}$ & 133 & Journal of Applied Psychology & 49 & Journal of Political Economy & 24 \\
\hline 3 & Journal of Accounting Research & 122 & Journal of Finance & 44 & Quarterly Journal of Economics & 23 \\
\hline 4 & Journal of Financial Economics & 66 & Journal of Financial Economics & 38 & $\begin{array}{l}\text { Journal of Accounting } \\
\text { and Economics }\end{array}$ & 22 \\
\hline 5 & $\begin{array}{l}\text { Auditing: A Journal of Practice } \\
\text { \& Theory }\end{array}$ & 48 & $\begin{array}{l}\text { Journal of Personality } \\
\text { and Social Psychology }\end{array}$ & 32 & Public Choice & 17 \\
\hline 6 & Journal of Finance & 48 & $\begin{array}{l}\text { Journal of Organizational } \\
\text { Behavior }\end{array}$ & 30 & Econometrica & 16 \\
\hline 7 & $\begin{array}{l}\text { Contemporary Accounting } \\
\text { Research. }\end{array}$ & 42 & Journal of Marketing & 27 & Economic Journal & 14 \\
\hline 8 & Accounting Horizons. & 41 & $\begin{array}{l}\text { Academy of Management } \\
\text { Journal }\end{array}$ & 26 & Journal of Health Economics & 11 \\
\hline 9 & $\begin{array}{l}\text { Behavioral Research } \\
\text { in Accounting. }\end{array}$ & 37 & $\begin{array}{l}\text { Academy of Management } \\
\text { Review }\end{array}$ & 19 & Journal of Economic Literature & 9 \\
\hline 10 & $\begin{array}{l}\text { Accounting, Organizations } \\
\text { and Society }\end{array}$ & 24 & Journal of Consumer Research & 19 & Journal of Monetary Economics & 9 \\
\hline 11 & Academy of Management & 18 & Journal of Management & 19 & Journal of Risk and Uncertainty & 9 \\
\hline & Review & & & & & \\
\hline 12 & $\begin{array}{l}\text { International Journal } \\
\text { of Accounting }\end{array}$ & 15 & Journal of Social Psychology & 14 & $\begin{array}{l}\text { American Journal } \\
\text { of Public Health }\end{array}$ & 8 \\
\hline 13 & Managerial Auditing Journal, & 13 & Journal of Business Research & 13 & $\begin{array}{l}\text { Review of Economics } \\
\text { and Statistics }\end{array}$ & 8 \\
\hline 14 & $\begin{array}{l}\text { Journal of Accounting, Auditing, } \\
\text { and Finance }\end{array}$ & 12 & Journal of Marketing Research & 13 & Applied Economics & 7 \\
\hline 15 & Journal of Political Economy & 12 & European Journal of Marketing & 12 & Journal of Accounting Research & 7 \\
\hline 16 & $\begin{array}{l}\text { Academy of Management } \\
\text { Journal }\end{array}$ & 11 & $\begin{array}{l}\text { Journal of Business } \\
\text { and Psychology }\end{array}$ & 12 & $\begin{array}{l}\text { Journal of Development } \\
\text { Economics }\end{array}$ & 7 \\
\hline 17 & $\begin{array}{l}\text { Journal of Accounting } \\
\text { and Publik Policy }\end{array}$ & 11 & $\begin{array}{l}\text { Administrative Science } \\
\text { Quarterly }\end{array}$ & 11 & $\begin{array}{l}\text { Journal of International } \\
\text { Economics }\end{array}$ & 7 \\
\hline 18 & American Economics Review & 10 & Psychological Bulletin & 11 & Accounting Review & 7 \\
\hline 19 & Strategic Management Journal & 10 & $\begin{array}{l}\text { Journal of Occupational Health } \\
\text { Psychology }\end{array}$ & 10 & $\begin{array}{l}\text { American Political Science } \\
\text { Review }\end{array}$ & 6 \\
\hline 20 & $\begin{array}{l}\text { Accounting and Business } \\
\text { Research }\end{array}$ & 9 & Journal of Vocational Behavior & 10 & European Economic Review & 6 \\
\hline dst & $\begin{array}{l}\text { Young Economists Journal dan } \\
229 \text { judul jurnal lainnya }\end{array}$ & 1 & $\begin{array}{l}\text { World Journal of Management } \\
\text { dan } 255 \text { judul jurnal lainnya }\end{array}$ & 1 & $\begin{array}{l}\text { Youth \& Society dan } 265 \text { judul } \\
\text { jurnal lainnya }\end{array}$ & 1 \\
\hline
\end{tabular}

Sumber: Data diolah 2016 
masing judul jurnal yang disitir yaitu Journal of Business Ethics dan American Economic Review, masing-masing disitir 56 kali dan 30 kali. Setelah dilakukan pengecekan pada database EBSCO dan
ProQuest dari 20 besar jurnal yang digunakan, ditemukan beberapa judul jurnal yang tidak terdapat pada dua database tersebut. Hasilnya dapat dilihat pada tabel 5 .

Tabel 5 Daftar jurnal tidak tersedia pada database EBSCO dan ProQuest untuk penyusunan disertasi pada tiga jurusan di FEB UGM

\begin{tabular}{llll}
\hline \multirow{2}{*}{ No } & \multicolumn{1}{c}{ Jurusan Akuntansi } & \multicolumn{1}{c}{ Jurusan Manajemen } & \multicolumn{1}{c}{ Jurusan Ilmu Ekonomi } \\
\cline { 2 - 4 } & \multicolumn{1}{c}{ Judul } & \multicolumn{1}{c}{ Judul } & Judul \\
\hline 1 & Chapter 4 Journal of Financial Economics & Journal of Financial Economics & Journal of Health Economics \\
\hline 2 & Accounting, Organizations and Society & $\begin{array}{l}\text { Journal of Personality and Social } \\
\text { Psychology }\end{array}$ & Journal of Monetary Economics \\
\hline 3 & International Journal of Accounting & Journal of Business Research, & Journal of International Economics \\
\hline 4 & Chapter 5 & Psychological Bulletin & European Economic Review \\
\hline 5 & & Journal of Vocational Behavior. & \\
\hline
\end{tabular}

Sumber: Data diolah 2016

Tabel 6. Persentase ketersediaan jurnal dalam database Business Source Complete dan ABI/INFORM Complete

\begin{tabular}{cccc}
\hline Jenis Karya Tulis & Jurusan & Database EBSCO (\%) & Database ProQuest (\%) \\
\hline \multirow{3}{*}{ Tesis } & Akuntansi & $31,03 \%$ & $29,65 \%$ \\
\cline { 2 - 4 } & Manajemen & $29,36 \%$ & $33,60 \%$ \\
\cline { 2 - 4 } & Ilmu Ekonomi & $28,20 \%$ & 32,41 \\
\cline { 2 - 4 } Disertasi & Akuntansi & $35,13 \%$ & $35,47 \%$ \\
\cline { 2 - 4 } & Manajemen & $41,13 \%$ & $31,10 \%$ \\
\hline
\end{tabular}

Sumber: Data diolah 2016

\section{Ketersediaan Jurnal dalam Database Business Source Complete dan ABI/INFORM Complete}

Perhitungan persentase ketersediaan jurnal pada masing-masing database untuk penyusunan tesis dan disertasi pada masing-masing jurusan dapat dilihat pada tabel 6.

Pada masing-masing 20 besar judul jurnal yang disitir dalam penyusunan tesis dan disertasi setiap jurusan diolah kembali, dan menghasilkan 20 besar jurnal dengan frekuensi disitir lebih tinggi. Setelah dilakukan pengecekan ketersediaannya pada dua database tersebut, ditemukan bahwa database EBSCO lebih banyak menyediakan judul jurnal sebagai sitiran dalam penyusunan tesis dan disertasi. Database ProQuest lebih sedikit menyediakan judul jurnal sebagai sitiran dalam penyusunan tesis dan disertasi, meskipun tahun penerbitannya pada rentang tahun tertentu saja. Selain itu hanya ada dua judul jurnal yang dapat diakses secara fulltext sampai saat ini yaitu Journal Business Ethics.

Apabila 20 besar judul jurnal yang disitir dalam penyusunan tesis dan disertasi dilakukan pengecekan pada ranking jurnal berdasar klasifikasi pemeringkatan jurnal dari ESSEC Ranking of Journal 2016, ditemukan 17 judul jurnal termasuk pada kelompok tertinggi yaitu "Leading Journal". Jurnal dalam kelompok tersebut merupakan jurnal terkemuka dengan kualitas tinggi serta berkontribusi besar bagi perkembangan akademik. Journal of Banking and Finance termasuk kelompok kedua, sedangkan Journal of Organizations Behavior dan Aditing: A Journal of Practice \& Theory termasuk pada kelompok ketiga. Banyaknya jurnal yang termasuk dalam Leading Journal yang digunakan sebagai sitiran dalam penyusunan tesis dan disertasi tentunya akan mempengaruhi kualitas karya tulis yang dihasilkan. 


\section{Tingkat kesamaan judul jurnal dalam database Business Source Complete dan database ABI/INFORM Complete.}

Berdasarkan hasil analisis ditemukan bahwa tingkat kesamaan jurnal baik dalam database Business Source Complete dan database ABI/INFORM Complete yang disitir dalam tesis dan disertasi FEB UGM pada masing-masing jurusan dapat dilihat pada tabel 7 .

Tabel 7. Judul-judul jurnal disitir dalam tesis dan disertasi masing-masing jurusan dan tersedia di database EBSCO dan ProQuest

\begin{tabular}{|c|c|c|c|c|c|c|}
\hline \multirow{2}{*}{ No } & \multicolumn{3}{|c|}{ Tesis } & \multicolumn{3}{|c|}{ Disertasi } \\
\hline & Akuntansi & Manajemen & I.Ekonomi & Akuntansi & Manajemen & I.Ekonomi \\
\hline 1 & $\begin{array}{l}\text { Academy of } \\
\text { Management Journal }\end{array}$ & $\begin{array}{l}\text { Academy of } \\
\text { Management Journal }\end{array}$ & $\begin{array}{l}\text { American } \\
\text { Economic Review }\end{array}$ & $\begin{array}{l}\text { Contemporary } \\
\text { Accounting Research }\end{array}$ & $\begin{array}{l}\text { Journal of Business } \\
\text { Ethics }\end{array}$ & $\begin{array}{l}\text { American Economic } \\
\text { Review }\end{array}$ \\
\hline 2 & $\begin{array}{l}\text { Accounting \& } \\
\text { Business Research }\end{array}$ & $\begin{array}{l}\text { Academy of } \\
\text { Management } \\
\text { Perspectives }\end{array}$ & $\begin{array}{l}\text { Annals of Regional } \\
\text { Science }\end{array}$ & Accounting Horizons & $\begin{array}{l}\text { Journal of } \\
\text { Organizational } \\
\text { Behavior }\end{array}$ & Public Choice \\
\hline 3 & Accounting Horizons & $\begin{array}{l}\text { Academy of } \\
\text { Management Review }\end{array}$ & $\begin{array}{l}\text { ASEAN Economic } \\
\text { Bulletin }\end{array}$ & $\begin{array}{l}\text { Behavioral Research } \\
\text { in Accounting }\end{array}$ & Journal of Marketing & $\begin{array}{l}\text { Journal of Economic } \\
\text { Literature }\end{array}$ \\
\hline 4 & $\begin{array}{l}\text { American Business } \\
\text { Law Journal }\end{array}$ & $\begin{array}{l}\text { Academy } \\
\text { of Marketing }\end{array}$ & Studies Journal & $\begin{array}{l}\text { Atlantic Economic } \\
\text { Journal }\end{array}$ & $\begin{array}{l}\text { Journal of } \\
\text { Accounting, Auditing, } \\
\text { and Finance }\end{array}$ & $\begin{array}{l}\text { Academy of } \\
\text { Management Journal } \\
\text { Journal of Risk and } \\
\text { Uncertainty }\end{array}$ \\
\hline 5 & $\begin{array}{l}\text { American Journal of } \\
\text { Political Science }\end{array}$ & Accounting Horizons & $\begin{array}{l}\text { Brookings Papers on } \\
\text { Economic Activity }\end{array}$ & $\begin{array}{l}\text { Strategic } \\
\text { Management Journal }\end{array}$ & $\begin{array}{l}\text { Academy of } \\
\text { Management Review }\end{array}$ & $\begin{array}{l}\text { American Journal of } \\
\text { Public Health }\end{array}$ \\
\hline 6 & $\begin{array}{l}\text { Annual Review of } \\
\text { Sociology }\end{array}$ & Accounting Review & Challenge & $\begin{array}{l}\text { Accounting and } \\
\text { Business Research }\end{array}$ & $\begin{array}{l}\text { Journal of } \\
\text { Management }\end{array}$ & Management Science \\
\hline 7 & $\begin{array}{l}\text { Asia Pacific } \\
\text { Management Review }\end{array}$ & $\begin{array}{l}\text { Administrative } \\
\text { Science Quarterly }\end{array}$ & $\begin{array}{l}\text { Contemporary } \\
\text { Economic Policy }\end{array}$ & $\begin{array}{l}\text { Review of } \\
\text { Accounting Studies }\end{array}$ & $\begin{array}{l}\text { Journal of Social } \\
\text { Psychology }\end{array}$ & $\begin{array}{l}\text { Review of Economic } \\
\text { Studies }\end{array}$ \\
\hline 8 & $\begin{array}{l}\text { Australian } \\
\text { Accounting Review }\end{array}$ & $\begin{array}{l}\text { American Business } \\
\text { Review }\end{array}$ & Demography & $\begin{array}{l}\text { Accounting and } \\
\text { Finance }\end{array}$ & $\begin{array}{l}\text { Journal of Marketing } \\
\text { Research }\end{array}$ & $\begin{array}{l}\text { Journal of Economic } \\
\text { Growth }\end{array}$ \\
\hline 9 & $\begin{array}{l}\text { Australian Journal of } \\
\text { Management }\end{array}$ & $\begin{array}{l}\text { American Economic } \\
\text { Review }\end{array}$ & $\begin{array}{l}\text { Eastern Economic } \\
\text { Journal }\end{array}$ & $\begin{array}{l}\text { Journal of } \\
\text { Management }\end{array}$ & $\begin{array}{l}\text { Journal of Business } \\
\text { and Psychology }\end{array}$ & $\begin{array}{l}\text { Journal of Economic } \\
\text { Perspectives }\end{array}$ \\
\hline 10 & $\begin{array}{l}\text { Behavioral Research } \\
\text { in Accounting }\end{array}$ & $\begin{array}{l}\text { Annual Review of } \\
\text { Sociology }\end{array}$ & Economic Record & $\begin{array}{l}\text { Journal of Business } \\
\text { Ethics }\end{array}$ & $\begin{array}{l}\text { Administrative } \\
\text { Science Quarterly }\end{array}$ & $\begin{array}{l}\text { Journal of Money, } \\
\text { Credit and Banking }\end{array}$ \\
\hline 11 & $\begin{array}{l}\text { Brigham Young } \\
\text { University Law } \\
\text { Review }\end{array}$ & $\begin{array}{l}\text { Asean Economic } \\
\text { Bulletin }\end{array}$ & $\begin{array}{l}\text { Economics of } \\
\text { Governance }\end{array}$ & $\begin{array}{l}\text { Journal of Financial } \\
\text { and Quantitative } \\
\text { Analysis }\end{array}$ & $\begin{array}{l}\text { American Economic } \\
\text { Review }\end{array}$ & Accounting Horizons \\
\hline 12 & $\begin{array}{l}\text { Business Strategy and } \\
\text { the Environment }\end{array}$ & $\begin{array}{l}\text { Asia Pacific Journal } \\
\text { of Management }\end{array}$ & Empirical Economics & $\begin{array}{l}\text { Journal of } \\
\text { International } \\
\text { Accounting Research }\end{array}$ & $\begin{array}{l}\text { Journal of Financial } \\
\text { and Quantitative } \\
\text { Analysis }\end{array}$ & $\begin{array}{l}\text { Journal of Applied } \\
\text { Econometrics }\end{array}$ \\
\hline 13 & $\begin{array}{l}\text { California } \\
\text { Management Review }\end{array}$ & $\begin{array}{l}\text { Australian Journal of } \\
\text { Management }\end{array}$ & $\begin{array}{l}\text { Harvard Business } \\
\text { Review }\end{array}$ & $\begin{array}{l}\text { Public Administration } \\
\text { Review. }\end{array}$ & $\begin{array}{l}\text { Journal of Personal } \\
\text { Selling and Sales } \\
\text { Management }\end{array}$ & $\begin{array}{l}\text { Journal of Economic } \\
\text { Development }\end{array}$ \\
\hline 14 & $\begin{array}{l}\text { Columbia Law } \\
\text { Review }\end{array}$ & $\begin{array}{l}\text { Bank Investment } \\
\text { Consultant }\end{array}$ & $\begin{array}{l}\text { Health Services \& } \\
\text { Outcomes Research } \\
\text { Methodology }\end{array}$ & Management Science & Journal of Marketing & $\begin{array}{l}\text { Review of Accounting } \\
\text { Studies }\end{array}$ \\
\hline 15 & $\begin{array}{l}\text { Contemporary } \\
\text { Accounting Research }\end{array}$ & $\begin{array}{l}\text { Business Intelligence } \\
\text { Journal }\end{array}$ & $\begin{array}{l}\text { Industrial and Labor } \\
\text { Relations Review }\end{array}$ & $\begin{array}{l}\text { Group Decision and } \\
\text { Negotiation }\end{array}$ & Journal of Psychology & $\begin{array}{l}\text { Review of World } \\
\text { Economics }\end{array}$ \\
\hline 16 & $\begin{array}{l}\text { Contemporary } \\
\text { Economic Policy }\end{array}$ & $\begin{array}{l}\text { Business Renaissance } \\
\text { Quarterly }\end{array}$ & Interfaces & $\begin{array}{l}\text { Harvard Bussiness } \\
\text { Review }\end{array}$ & Personnel Psychology & $\begin{array}{l}\text { Southern Economic } \\
\text { Journal }\end{array}$ \\
\hline 17 & $\begin{array}{l}\text { Corporate } \\
\text { Governance: An } \\
\text { International Review }\end{array}$ & $\begin{array}{l}\text { Business Strategy and } \\
\text { The Environment }\end{array}$ & $\begin{array}{l}\text { International } \\
\text { Advances in } \\
\text { Economic Research }\end{array}$ & Journal of Business & $\begin{array}{l}\text { Financial } \\
\text { Management }\end{array}$ & $\begin{array}{l}\text { Journal of Applied } \\
\text { Economics }\end{array}$ \\
\hline 18 & $\begin{array}{l}\text { Corporate Social } \\
\text { Responsibility and } \\
\text { Environmental } \\
\text { Management }\end{array}$ & $\begin{array}{l}\text { California } \\
\text { Management Review }\end{array}$ & $\begin{array}{l}\text { International Journal } \\
\text { of Business Science } \\
\text { and Applied } \\
\text { Management }\end{array}$ & $\begin{array}{l}\text { Annual Review of } \\
\text { Sociology }\end{array}$ & $\begin{array}{l}\text { Harvard Business } \\
\text { Review }\end{array}$ & $\begin{array}{l}\text { Journal of } \\
\text { International } \\
\text { Business Studies }\end{array}$ \\
\hline 19 & Decision Sciences & $\begin{array}{l}\text { Canadian Journal of } \\
\text { Administrative } \\
\text { Sciences }\end{array}$ & $\begin{array}{l}\text { International Journal } \\
\text { of Economic } \\
\text { Perspectives }\end{array}$ & $\begin{array}{l}\text { Australian Journal } \\
\text { of Management }\end{array}$ & $\begin{array}{l}\text { Health Marketing } \\
\text { Quarterly }\end{array}$ & Pharmacoeconomics \\
\hline 20 & Demography & $\begin{array}{l}\text { Career Development } \\
\text { Quarterly }\end{array}$ & $\begin{array}{l}\text { International Journal } \\
\text { of Finance and } \\
\text { Economics }\end{array}$ & $\begin{array}{l}\text { Financial Analysts } \\
\text { Journal }\end{array}$ & $\begin{array}{l}\text { Journal of } \\
\text { Occupational and } \\
\text { Organizational } \\
\text { Psychology }\end{array}$ & Regional Studies \\
\hline dst & The Financial Revie & $\begin{array}{l}\text { Training and } \\
\text { Development Journal }\end{array}$ & Urban Studies & $\begin{array}{l}\text { Thunderbird } \\
\text { International Busine } \\
\text { Review }\end{array}$ & $\begin{array}{l}\text { Training and } \\
\text { Development Journal }\end{array}$ & $\begin{array}{l}\text { The Journal of Social } \\
\text { Psychology }\end{array}$ \\
\hline
\end{tabular}

Sumber: Data diolah 2016 
Hasil analisis perhitungan kesamaan jurnal yang disitir dan tersedia pada dua database secara keseluruhan sebesar $24,88 \%$ untuk penyusunan tesis, dan $27,81 \%$ untuk penyusunan disertasi. Rincian selengkapnya tingkat kesamaan jurnal untuk penyusunan tesis dan disertasi pada masing-masing jurusan program magister sains dan doktor FEB UGM disajikan pada tabel 8 .

Tabel 8. Tingkat kesamaan jurnal disitir pada masing-masing jurusan dan tersedia pada dua database EBSCO dan ProQuest

\begin{tabular}{llrr}
\hline $\begin{array}{l}\text { Jenis karya } \begin{array}{c}\text { tulis } \\
\text { tulis }\end{array} \\
\text { Tesis }\end{array}$ & \multicolumn{1}{c}{ Jurusan } & $\begin{array}{c}\text { judul jurnal } \\
\text { sama }\end{array}$ & Persentase \\
& Akuntansi & 111 & $22,98 \%$ \\
\cline { 2 - 4 } & Manajemen & 140 & $25,50 \%$ \\
\cline { 2 - 4 } & Ilmu Ekonomi & 61 & 27,48 \\
\hline Disertasi & Akuntansi & 63 & $26,47 \%$ \\
\cline { 2 - 4 } & Manajemen & 91 & 29,26 \\
\cline { 2 - 4 } & Ilmu Ekonomi & 68 & $27,31 \%$ \\
\hline
\end{tabular}

Sumber: Data diolah 2016

\section{Tahun terbit jurnal}

Tahun penerbitan jurnal dikelompokkan dalam rentang waktu lima tahun. Tahun penerbitan paling lama ditentukan sebelum tahun 1950, karena ada beberapa jurnal yang disitir diterbitkan sebelum tahun 1950. Apabila dibuat grafik mengenai penggunaannya sebagai sitiran berdasarkan tahun penerbitan, akan terlihat ada peningkatan dalam penggunaan jurnal rentang waktu tahun 2001-2010 (lihat gambar 3).

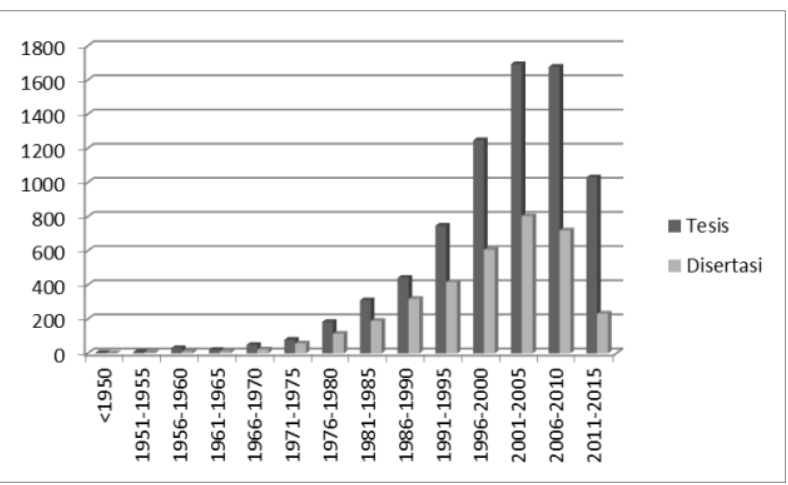

Gambar 3. Penggunaan jurnal dalam penyusunan tesis dan disertasi semua jurusan

berdasarkan tahun penerbitan (rentang 5 tahun)
6. Pemanfaatan jurnal dalam database EBSCO "Business Source Complete" dan database ProQuest "ABI/INFORM Complete"

Pemanfaatan jurnal dalam database EBSCO "Business Source Complete" dan database ProQuest "ABI/INFORM Complete" merupakan penggunaan judul jurnal yang disitir dalam penyusunan tesis dan disertasi mahasiswa Program Magister Sains dan Doktor FEB. Sebelum dilakukan analisis, terlebih dahulu dilakukan pengecekan pada database EBSCO dan ProQuest mengenai jumlah jurnal yang dapat diakses secara fulltext. Hasilnya menunjukkan bahwa ada 2012 judul yang terdapat pada database EBSCO, dan 2232 judul database ProQuest. Grafik pemanfaatan jurnal pada masing-masing database dapat dilihat pada gambar 4 .

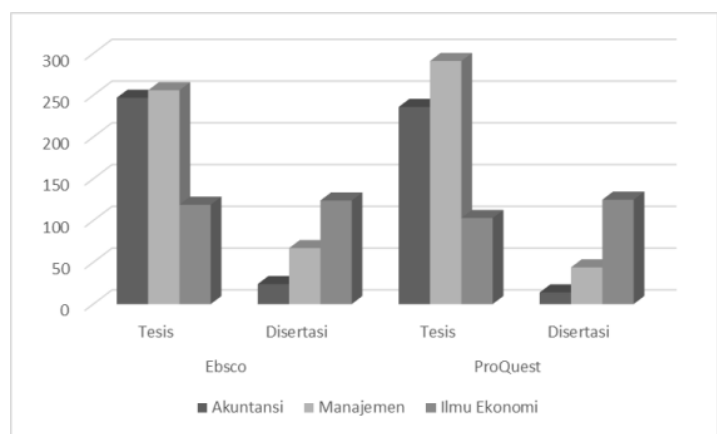

Gambar 4. Pemanfaatan database EBSCO dan ProQuest masing-masing dari jumlah total 2012 dan 2232 judul jurnal fulltext.

Hasil perhitungan menunjukkan bahwa persentase pemanfaatan jurnal dalam tesis dan disertasi masing-masing jurusan dapat dilihat pada tabel 9.

Tabel 9. Persentase pemanfaatan jurnal dari Database EBSCO dan ProQuest pada tesis dan disertasi masing-masing jurusan

\begin{tabular}{cccc}
\hline $\begin{array}{c}\text { Jenis } \\
\text { Karya } \\
\text { Tulis }\end{array}$ & Jurusan & $\begin{array}{c}\text { Database } \\
\text { EBSCO (\%) }\end{array}$ & $\begin{array}{c}\text { Database } \\
\text { ProQuest (\%) }\end{array}$ \\
\hline Tesis & Akuntansi & 12,28 & 10,57 \\
\hline & Manajemen & 12,72 & 13,13 \\
\hline & $\begin{array}{c}\text { Ilmu } \\
\text { Ekonomi }\end{array}$ & 5,92 & 4,62 \\
\hline Disertasi & Akuntansi & 6,16 & 5,11 \\
\hline & Manajemen & 8,3 & 6,45 \\
& Ilmu & 6,16 & 5,6 \\
\hline
\end{tabular}

Sumber: Data diolah 2016 
Tabel 9 menunjukkan bahwa pemanfaatan jurnal pada database EBSCO "Business Source Complete" dan database ProQuest "ABI/INFORM Complete" sebagai sitiran dalam penyusunan tesis dan disertasi cenderung rendah.

\section{E. KESIMPULAN DAN SARAN}

\section{Kesimpulan}

Berdasarkan hasil analisis dan pembahasan, dapat disimpulkan sebagai berikut:

a. Judul jurnal dalam database Business Source Complete dan database ABI/INFORM Complete yang disitir dengan frekuensi tertinggi yaitu Academy of Management Journal. Penyusunan tesis Jurusan Akuntansi, Manajemen, dan Ilmu Ekonomi frekuensi tertinggi jurnal disitir berjudul American Economics Review. Penyusunan disertasi Jurusan Akuntansi, Manajemen, dan Ilmu Ekonomi frekuensi tertinggi jurnal disitir masing-masing berjudul Contemporary Accounting Research, Journal of Business Ethics, Amerian Economics Review.

b. Ketersediaan jurnal dalam database Business Source Complete terbesar 31,03\% sebagai sitiran dalam penyusunan tesis Jurusan Akuntansi dan 41,13\% untuk penyusunan disertasi Jurusan Manajemen. Ketersediaan jurnal dalam database ABI/INFORM Complete terbesar 33,60\% sebagai sitiran dalam penyusunan tesis Jurusan Manajemen, dan 35,47\% untuk penyusunan disertasi Jurusan Manajemen.

c. Tingkat kesamaan judul jurnal dalam database Business Source Complete dan database ABI/INFORM Complete sebagai sitiran penyusunan tesis Jurusan Akuntansi 22,98\%, Manajemen 25,50\%, dan Ilmu Ekonomi 27,48\%. Kemudian sebagai sitiran penyusunan disertasi Jurusan Akuntansi 26,47\%, Manajemen 29,26\%, dan Ilmu Ekonomi 27,31\%. Tingkat kesamaan secara keseluruhan untuk penyusunan tesis dan disertasi masingmasing sebesar $24,88 \%$ dn $27,81 \%$.

d. Tahun penerbitan jurnal sebagai sitiran penyusunan tesis Jurusan Akuntansi frekuensi tertinggi dalam rentang tahun
2006-2010 yaitu 639 sitiran. Sementara untuk penyusunan tesis Jurusan Manajemen dengan rentang tahun 20012005 berjumlah 843 sitiran, dan Jurusan Ilmu Ekonomi dengan rentang tahun 20062010 berjumlah 257 sitiran. Jurnal yang disitir terbanyak dalam penyusunan disertasi Jurusan Akuntansi yaitu 332 sitiran, Manajemen 285 sitiran, dan Ilmu Ekonomi 187 sitiran. Ketiga jurusan menggunakan sitiran terbanyak dengan rentang tahun terbit jurnal yang sama, yaitu tahun 2001-2005.

e. Secara umum tingkat pemanfaatan jurnal dalam database EBSCO "Business Source Complete" dan ProQuest "ABI/INFORM Complete" sebagai sitiran penyusunan tesis dan disertasi mahasiswa program magister sains dan doktor FEB UGM masih sangat kurang, yaitu dibawah $20 \%$.

\section{Saran}

a. Pelatihan akses database perlu dilakukan secara berkala dengan melibatkan peserta mahasiswa dari satu klaster.

b. Jurnal-jurnal yang akses fulltext-nya (delay/embargo) utamanya untuk jurnal inti, perlu dilakukan langganan langsung dari penerbit. Hal ini dapat dilakukan oleh masing-masing fakultas sesuai kebutuhan, dengan dana yang tersedia melalui RKAT fakultas.

c. Pengelolaan e-journal yang dilanggan UGM harus dioptimalkan oleh masingmasing perpustakaan, agar sumber informasi yang tersedia lebih bernilai guna, misalnya dengan pembuatan pathfinder.

d. Penelitian yang sama dapat dilakukan untuk koleksi tesis Program Studi Magister Manajemen UGM dan laporan penelitian dosen, mengingat database ProQuest banyak dimanfaatkan dalam penyusunan tesis dan disertasi Jurusan Manajemen serta banyaknya jumlah artikel diunduh oleh pemustaka.

e. Penelitian seperti ini dapat dilakukan di masing-masing fakultas sebagai bentuk evaluasi penggunaan e-resource yang dilanggan, dengan harapan hemat anggaran dan memperoleh hasil yang optimal. 


\section{DAFTAR PUSTAKA}

Abeyrathne, Dilani K. 2015. Citation analysis of dissertations for collection development. Collection Building, Vol. 34 (2) pages. 30 $40 \mathrm{http}: / / \mathrm{ww}$.emeraldinsight.com/ doi/pdfplus/10.1108/CB-11-2014-0055. Download: 24 April 2016.

Anyaoku, E.N. and Anunobi, C.V. 2014. Measuring HINARI use in Nigeria through a citation analysis of Nigerian Journal of Clinical Practice. Health Information \& Libraries Journal Vol. 31 (2) pages 148 155.onlinelibrary.wiley. com/doi/ 10.1111/hir.12056/abstract. Download: 20 April 2016.

Arikunto, S. 1998. Manajemen penelitian, Rineka Cipta, Jakarta

Arikunto, S. 2002. Prosedur penelitian: Suatu pendekatan praktek, Rineka Cipta, Jakarta.

Banateppanvar, Koteppa, Biradar,B.S., Kannappanavar, B.U. 2013. Citation analysis of doctoral theses in botany submitted to Kuvempu University, India: a case study", Collection Building, Vol. 32 (1), pages $12-21$

http://www.emeraldinsight.com/doi/pdfplus/ 10.1108/01604951311295058. Download: 24April 2016

Becker, Deborah A. dan Chiware, Elisha R.T. 2015. Citation Analysis of Masters' Theses and Doctoral Dissertations: Balancing Library Collections With Students' Research Information Needs. The Journal of Academic Librarianship, Vol 41(5) September 2015, Pages: 613-620

Cooper, Diana, 2015. Bibliometric basics. Journal of the Medical Library Association Vol. 103 (4) October 2015. pages 217-219.

Departemen Pendidikan Nasional. 2005. Kamus besar bahasa Indonesia, Balai Pustaka, Jakarta.

Direktorat Jenderal Pendidikan Tinggi, 2012. Surat Dirjen Dikti No. 152/E/T/2012: Wajib publikasi ilmiah bagi S1/S2/S3. http://www.kopertis12.or.id. Download: 24April 2016.

Feather, John and Sturges, P. (Editor), 1997. International encyclopedia of information and library science, Routledge, London.
Feyereisen, P and Spoiden, A. 2009. Can Local Citation Analysis of Master's and Doctoral Theses help Decision-Making about the Management of the Collection of Periodicals? A Case Study in Psychology and Education Sciences. The Journal of Academic Librarianship. Vol 35 (6) pages 514-522 http://www.sciencedirect.com/ science/article/pii/S0099133309001608\#. Download: 24April 2016

Gasparotto, M. 2014. A ten year analysis of dissertation bibliographies from the Department of Spanish and Portuguese at Rutgers University", Collection Building, Vol. 33 (3) pages 86-89

Hartinah, S. 2002. "Analisis Sitiran (Citation Analysis)". Kumpulan Makalah Kursus Bibliometrika. Depok: Masyarakat Informetrika Indonesia. 20-23 Mei 2002.

Haycock, Laurel A. 2004. Citation analysis of education dissertations for collection development. Library Resource \& Techical Service. Vol 48(2), 102-106.

http://search.proquest.com/docview/216889831/ fulltextPDF/E49F9D587BEE47B0PQ/1?a ccountid=13771. Download: 20 April 2016

Hoffmann, K. and Doucette, L. 2012. A Review of citation analysis methodologies for collection management. College \& Research Libraries vol. 73 no. 4 pages: $321-335$. http://crl.acrl.org/ content/73/4/321 .full.pdf + html . Download: 24April 2016.

Iivonen, M., Nygrén, U., Valtari, A.,Heikkilä, T. 2009. Library collections contribute to doctoral studies", Library Management, Vol. 30 (3), pages. $185-203$ http:// www.emeraldinsight.com/doi/pdfplus/10. 1108/01435120910937 357 Download: 1 Maret 2016

Irianti, P. 2007. Analisis Sitiran Artikel Jurnal Psikologi UGM Tahun 1997-2006, Fakultas Adab dan Ilmu Budaya, UIN Sunan Kalijaga, Yogyakarta.

Kerlinger, Fred N. 1973. Foundations of behavioral research, Holt, Rinehart and Winston, New York

Krisyantono, R. 2007. Teknik praktis riset komunikasi: Disertai contoh praktis riset media, public relations, advertising, pemasaran, Kencana, Jakarta. 
Lasa Hs. 2009. Kamus kepustakawanan Indonesia, Pustaka Book, Yogyakarta

Nawawi, H. dan Hadari, M. 2006. Instrumen penelitian bidang sosial, Gadjah Mada University Press, Yogyakarta

Purwaningsih, Heni. 2013. Pemanfaatan Jurnal dalam Database EBSCO"Business Source Complete" Sebagai Sumber Rujukan dalam Penyusunan Skripsi Mahasiswa Jurusan Akuntansi Fakultas Ekonomika dan Bisnis UGM yang Lulus Pada Tahun 2011, Fakultas Adab dan Ilmu Budaya, UIN Sunan Kalijaga, Yogyakarta.

Rusydi, Ibnu. 2014. Pemanfaatan e-journal sebagai media informasi digital. Jurnal Iqra' vol. 08 (02) Oktober 2014 pages: 200-210. http://oaji.net/articles/2015/19371430103772.pdf. Download: 26 April 2016.

Sulistyo-Basuki. 2002. "Bibliometrika, Sainsmetrika dan Infrometrika". Kumpulan Makalah Kursus Bibliometrika. Depok: Masyarakat Informetrika Indonesia. 20-23 Mei 2002.
Surachman, A. 2014. Pengembangan e-resources: Salah satu upaya membangun perpustakaan digital. http:// www.academia.edu/7858407/ Pengembangan_E-Resources salah satu upaya membangun perpustakaan__digital. Download: 20 Aprì 2016.

Suryabrata, S. 1983. Metodologi penelitian, Rajawali, Jakarta.

Thanuskodi. S. 2012. Citation analysis of doctoral research in Botany submitted to Annamalai University. International Journal of Library Science Vol 1 (1) 2012 pages: 8-12. http://article.sapub.org/10.5923.j.library.2 0120101. 02.html. Download: 24 April 2016

Woodward, H., Rowland, F., McKnight, C., Pritchett, C., and Jack Meadows, J. 1998. Café Jus: an Electronic Journals User Survey. (https://journals. tdl.org/ jodi/index.php/jodi/article/view/12/11. Download 26April 2016. 